\title{
ORIGINAL ARTICLE \\ The effect of immunonutrition (glutamine, alanine) on fracture healing
}

\author{
Abdullah Küçükalp '*, Kemal Durak², Sarp Bayyurt ${ }^{3}$, Gürsel Sönmez ${ }^{4}$ and \\ Muhammed S. Bilgen ${ }^{2}$ \\ 'Department of Orthopaedic and Traumatology, Muammer Agim Gemlik State Hospital, Bursa, Turkey; ${ }^{2}$ Department \\ of Orthopaedics and Traumatology, Faculty of Medicine, Uludag University, Bursa, Turkey; ${ }^{3}$ Department of Pathology, \\ Faculty of Veterinary Medicine, Uludag University, Bursa, Turkey; ${ }^{4}$ Department of Orthopaedics and Traumatology, \\ Gaziantep Dr. Ersin Arslan State Hospital, Gaziantep, Turkey
}

Abstract

Background: There have been various studies related to fracture healing. Glutamine is an amino acid with an important role in many cell and organ functions. This study aimed to make a clinical, radiological, and histopathological evaluation of the effects of glutamine on fracture healing.

Methods: Twenty rabbits were randomly allocated into two groups of control and immunonutrition. A fracture of the fibula was made to the right hind leg. All rabbits received standard food and water. From post-operative first day for 30 days, the study group received an additional $2 \mathrm{ml} / \mathrm{kg} /$ day $20 \% \mathrm{~L}$-alanine L-glutamine solution via a gastric catheter, and the control group received $2 \mathrm{ml} / \mathrm{kg} /$ day isotonic via gastric catheter. At the end of 30 days, the rabbits were sacrificed and the fractures were examined clinically, radiologically, and histopathologically in respect to the degree of union.

Results: Radiological evaluation of the control group determined a mean score of 2.5 according to the orthopaedists and 2.65 according to the radiologists. In the clinical evaluation, the mean score was 1.875 for the control group and 2.0 for the study group. Histopathological evaluation determined a mean score of 8.5 for the control group and 9.0 for the study group.

Conclusion: One month after orally administered glutamine-alanine, positive effects were observed on fracture healing radiologically, clinically, and histopathologically, although no statistically significant difference was determined.

Keywords: fracture healing; glutamine; alanine; immunonutrition; antioxidant

Responsible Editor: Asim Duttaroy, University of Oslo, Norway.

Received: 2 I May 20 14; Revised: 9 September 20I4; Accepted: 8 October 20I4; Published: 3 November 2014

$\mathrm{T}$ he classical definition of a fracture is the breaking of the entirety of a bone from internal or external forces. The bone is healed by reconstruction of osseous tissue without any scarring (1). Fracture healing starts immediately after the injury and continues until the broken ends unite with the new bone tissue (2).

Studies have been made on many factors to accelerate fracture healing. Glutamine is an amino acid with an important role in several chemical reactions of many cell and organ functions (3). Among these are the energy source of cells such as fibroblasts, epithelial cells, enterocytes, lymphocytes, and macrophages. In addition, it is the most important precursor substance regulating protein synthesis in the nucleic acid biosynthesis of cells. By protecting tissues from free radical damage, and as a major antioxidant, glutamine shows positive effects by promoting glutathione synthesis (4-6). Several studies in literature have shown positive healing effects of glutamine on wound healing and on patients requiring critical care $(7,8)$. It is thought that this study can make a positive contribution to fracture healing by considering the accelerating effect of glutamine on wound healing.

\section{Materials and methods}

This study was approved by Uludag University Animal Experiments Local Ethics Committee and was carried out on $20 \mathrm{New}$ Zealand white rabbits, aged 3 months, weighing between 2.5 and $3.0 \mathrm{~kg}$, obtained from the Experimental Animal Breeding and Research Centre with the permission of the Deanery of Uludag University Medical Faculty. 


\section{Study plan - surgical technique}

The rabbits were randomly allocated into two groups of 10 as the immunonutrition group and the control group. Anaesthesia of $5 \mathrm{mg} / \mathrm{kg}$ xylazine and $35 \mathrm{mg} / \mathrm{kg}$ ketamine was administered intramuscularly to both groups. The rabbits were then laid down with the right hind leg uppermost. After disinfection of the fibular area with $10 \%$ free alcohol containing $10 \mathrm{~g}$ povidone iodine, a $1-2$ $\mathrm{cm}$ skin incision was made approximately $1 \mathrm{~cm}$ to the posterior of the fibula. By subcutaneous dissection, continuing to slide the skin over the fibula, the fibula shaft was reached. An oblique fracture was created using tissue scissors on the fibula corpus (Figs. 1 and 2).

After washing the surgical site with saline, the skin was closed. Povidone iodine was applied with a dressing, then transparent film dressing spray, leaving the wound uncovered. From the post-operative first day for 30 days, the immunonutrition group were given standard rabbit food and water with the addition of $2 \mathrm{ml} / \mathrm{kg} /$ day $20 \% \mathrm{~L}$-alanine and L-glutamine solution via a gastric catheter. The control group received $2 \mathrm{ml} / \mathrm{kg} /$ day isotonic via gastric catheter in addition to standard rabbit food and water. All the rabbits were sacrificed at the end of 30 days. By disarticulating the lower extremity where the fracture had been made, from the hip joint, the surrounding soft tissue was removed without any damage to the callus tissue. The fractures were examined clinically, radiologically, and histopathologically in respect to the degree of union.

Anterior-posterior and lateral radiographs were taken of the lower extremities removed from the rabbits. These radiographs were evaluated by five specialist doctors from the orthopaedics and traumatology department and five separate specialist doctors from the radiology department using the Lane and Sandhu (9) radiological scoring system to give a numerical value. In this system, the radiological findings are scored $0-4$, where $0=$ no healing, $1=$ callus formation, $2=$ the start of bone union, $3=$ the fracture line is starting to disappear, and $4=$ full union. The fibula union was subjectively evaluated by examination in two planes as described by Dimar et al. (10). This scoring

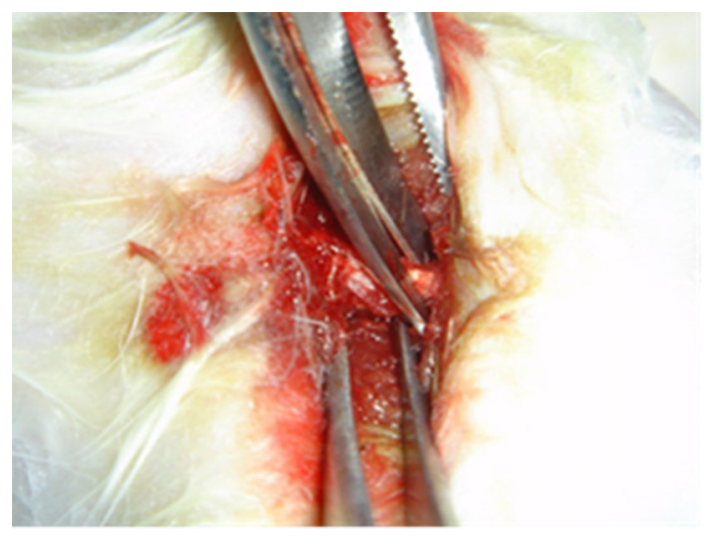

Fig. 1. Surgical fracture of the exposed rabbit fibula.

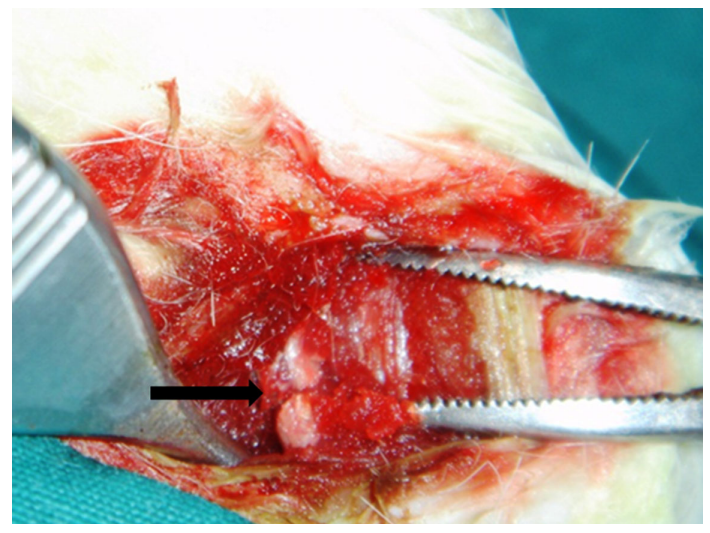

Fig. 2. Short oblique surgical fracture.

system grades the amount and quality of bone callus tissue through physical movement. A score of 0 indicates movement in both planes and therefore no union, a score of 1 indicates movement in one plane with moderate union and with a score of 4 , there is no movement and full union.

After the clinical and radiological evaluations, tissue from the prepared samples from the fracture union site were fixed in $10 \%$ concentration formalin and stored for 3 days. The electrolytic method was used for decalcification and accordingly the tissues were kept for 2 weeks in a decalcification solution, and changed every 2 days (11). The tissues were washed for $4 \mathrm{~h}$ in running water, then for $1 \mathrm{~h}$ in each of the following strengths of alcohol; 70, 80, 90,96 , and $100 \%$, kept overnight in xylol, then for $2 \mathrm{~h}$ in liquid paraffin before being fixed in paraffin blocks. The lamina prepared from 5-micron thickness sections cut by rotary microtome were stained with haematoxylin and eosin and examined by light microscope. Callus tissue was scored histopathologically using the system recommended by Huo et al. (12).

Statistical analysis was made by SPSS 13.0 packet program. Descriptive statistics were given as median, minimum, and maximum values. The Mann-Whitney $U$-test was used for comparison of the two independent groups and the Wilcoxon test for comparison of dependent groups. Spearman correlation analysis was used in the examination of the relationships between variables. A significance level of $p<0.05$ was accepted.

\section{Results}

In the first week of the study, two rabbits in the immunonutrition group aspirated the dipeptiven solution given by gastric catheter. One of the rabbits died within minutes of aspiration and the other on the following day. In the control group, in the first week, one rabbit trapped its right lower extremity in the cage while it was being cleaned and sustained a femoral fracture. A pelvipedal plaster was applied but the rabbit died 3 days later. In the second week, one rabbit in the control group was found dead in its cage 
of unknown causes. The study continued with eight rabbits in the immunonutrition group and eight rabbits in the control group. Throughout the study no surgical site infection developed in any of the rabbits. Apart from the rabbit that sustained a femoral fracture, no functional problems were observed in any rabbit other than the created fibula fracture.

\section{Radiological findings}

The radiological evaluation results determined the control group points from the orthopaedic and traumatology specialists to be mean 2.5 (minimum 0.4-maximum 3.6), and from the radiology specialists, mean 2.65 (minimum 0.6-maximum 3.8) (Figs. 3 and 4).

The immunonutrition group points from the orthopaedic and traumatology specialists were determined to be mean 3.42 (minimum 3.0-maximum 3.8), and from the radiology specialists, mean 3.35 (minimum 2.4-maximum 4.0) ( $p=0.13$ orthopaedists, $p=0.279$ radiologists, Fig. 5).

\section{Clinical examination results}

An orthopaedic doctor who was not involved in the experimental study made a subjective clinical examination of the relevant disarticulated extremities after removal from the soft tissue. In the clinical evaluation, the control group mean points were 1.875 (minimum 1.0-maximum 2.0 ), and the immunonutrition group mean points were 2.0 (minimum 2.0-maximum 2.0) $(p=0.721$, Fig. 6).

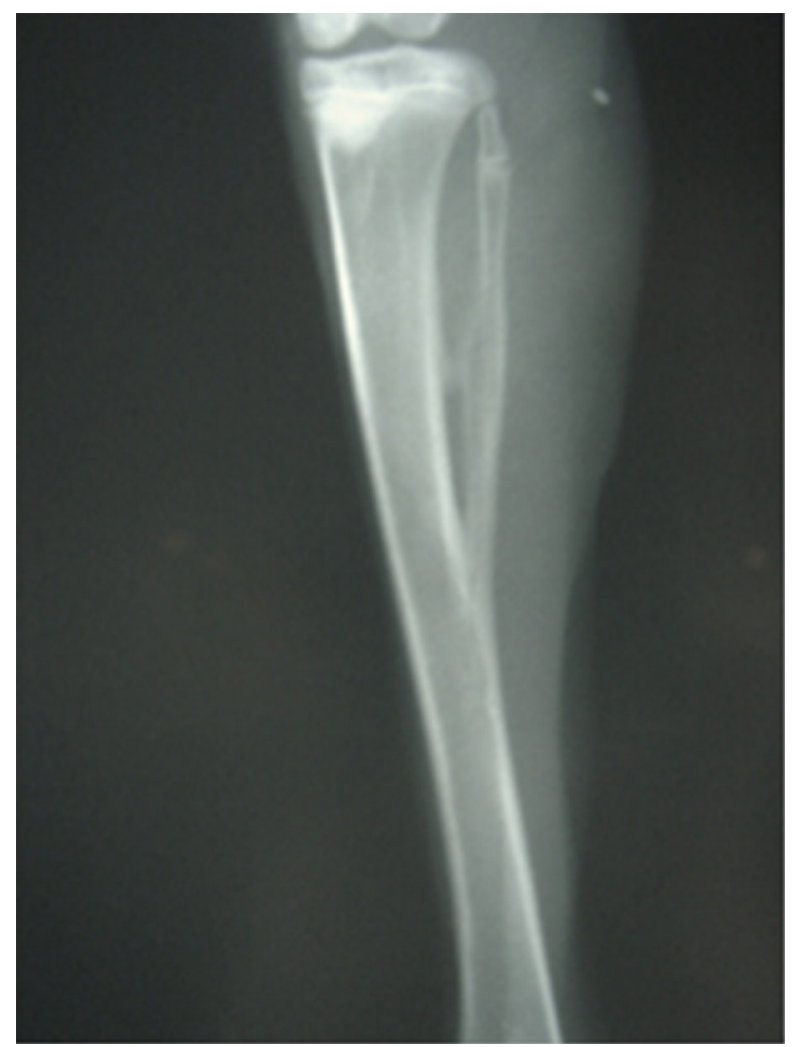

Fig. 3. Control group anterior-posterior radiograph.

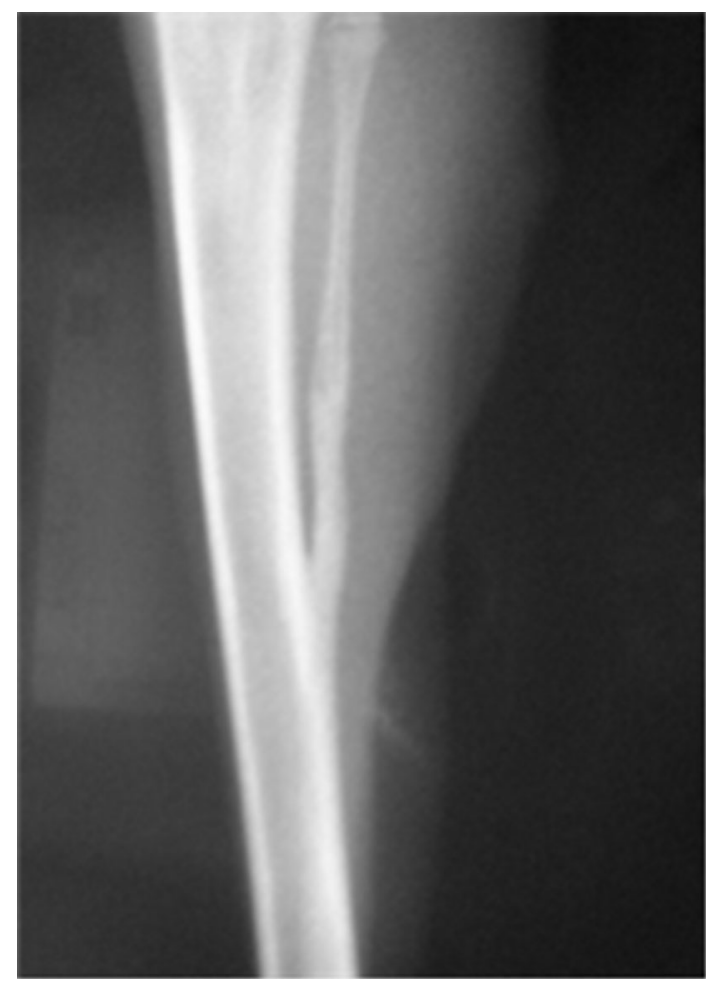

Fig. 4. Immunonutrition group anterior-posterior radiograph.

\section{Histopathological results}

Following the clinical and radiological examinations, the preparations were histopathologically evaluated according to the criteria described by Huo et al. (12). In this evaluation, the control group mean points were 8.5 (minimum 8.0-maximum 9.0), and the immunonutrition group mean points were 9.0 (minimum 9.0-maximum 9.0) (Figs. 7-11).

\section{Discussion and conclusion}

In recent years several scientific studies have focussed on glutamine as a non-essential amino acid as it has been determined to have significant physiological roles. Glutamine facilitates the process of rapid cell reproduction as it is a leading source of both energy and biosynthesis $(13,14)$. Particularly in critical cases such as multiple injuries, sepsis, or burns, glutamine is used as an essential amino acid as it undertakes the precursor task for nucleic acids, nucleotides, amino sugars, and proteins (3). Under catabolic conditions, glutamine takes on the aspects of an amino acid $(3,15)$. When muscle tissue is exposed to excessive stress, the most important of the amino acids which provide a repository of some amino acids, is glutamine (16). A fall in the level of glutamine is associated with poor clinical results, as starting with a decreased amount in the process of muscle destruction, morbidity and mortality rates may increase. Parenteral or enteral administration of glutamine to critical patients leads to 


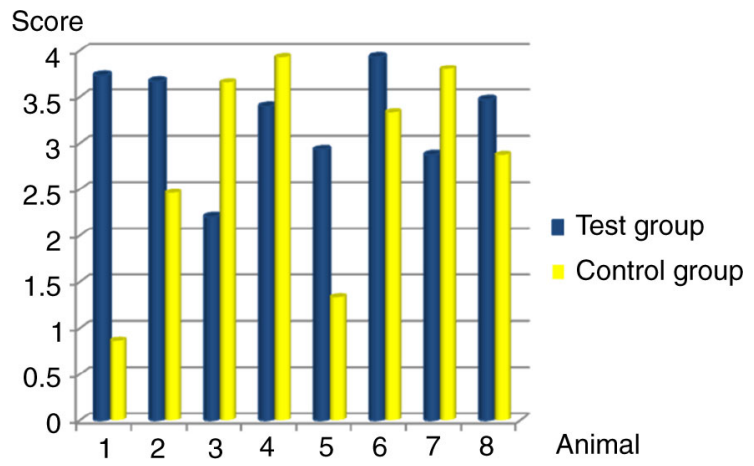

Fig. 5. Mean points distribution given by Orthopaedics and Radiology physicians.

decreased complications associated with sepsis and better functional results $(17,18)$. Glutamine has the essential properties of an amino acid in respect to affecting lymphocyte proliferation in the most appropriate way by neutrophil and macrophage functions (19-22). By eliminating a lack of glutamine, it is possible to restore nitrogen balance and improve immunosuppression (17).

To the best of our knowledge there are no studies on the effect of orally administered glutamine on fracture healing. In this study, taking various beneficial effects into consideration, it was thought that glutamine could make a positive contribution to fracture healing, and in this context, the similarity of wound healing to fracture healing was the guide.

As a single indeterminate structure, glutamine quickly becomes denatured in water. The dipeptide structure formed when glutamine is combined with alanine may remain stable in aqueous solutions. L-amino acids are more easily absorbed than D-amino acids (16). Therefore, in this study an L-alanine L-glutamine solution was used to achieve absorption with active transport of the glutamine and to prevent rapid denaturing.

In an experimental study of 50 rabbits with fibula fracture and femoral condyle defects, and orally nourished with essential amino acids containing lactose, Fini et al. (23) reported a positive effect on fracture healing. Although the current study investigated the effect on rabbit

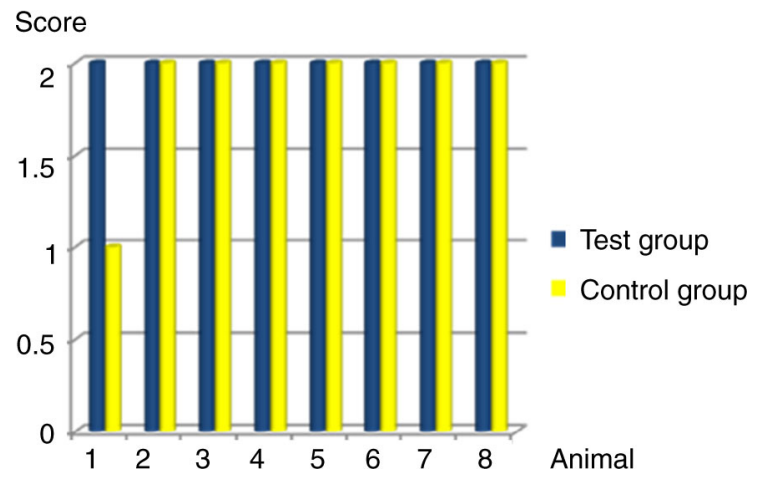

Fig. 6. Clinical points distribution of callus tissue.

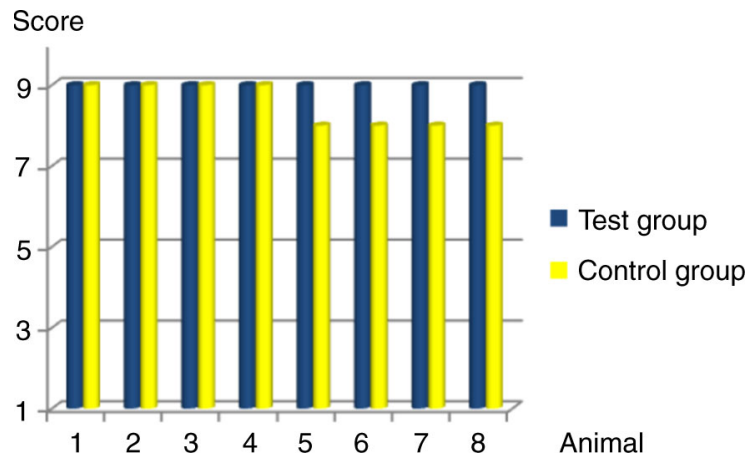

Fig. 7. Histopathological points distribution.

fibula fracture of glutamine as a different essential amino acid, both studies showed a similarity in respect to the chosen animal model and the choice of amino acid given. In the fracture model created in the rabbits, cartilage islands started to form on the sixth day of fracture healing, on the 12th day the centre was filled with cartilage tissue, and in the third and fourth week bone tissue replaced the cartilage showing complete union. Thus, in the current study, the experiment was terminated in the fourth week as a sufficient time for fracture healing in rabbits.

Although various techniques are used for the radiological evaluation of fracture healing, most of these have been shown to be inadequate as they are not objective and vary from person to person. In some studies, the bridging status between the fractured ends has been evaluated from direct radiographs $(9,24)$. In the current study, the widely used Lane and Sandhu (9) scoring system was used in the radiological evaluation by more than one orthopaedic, traumatology, and radiology specialist (25-28). We are of the opinion that this provides a more objective evaluation.

In clinical application, bone union is monitored with both physical examinations and radiological tests. Similarly, in the current study, the presence of bone union was

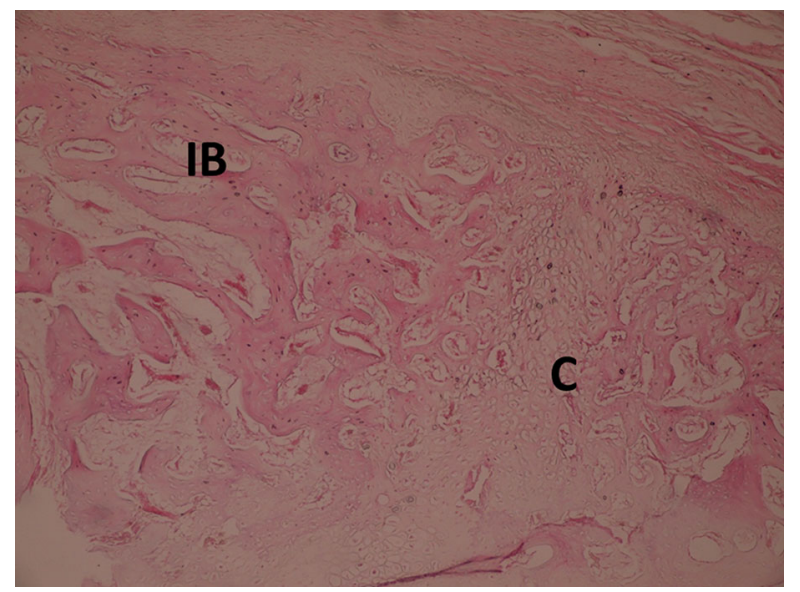

Fig. 8. Control group stage 8 recovery: Image shows immature bone (IB) and little cartilage (C) tissue (haemotoxylin and eosin staining $\times 100$ magnification). 


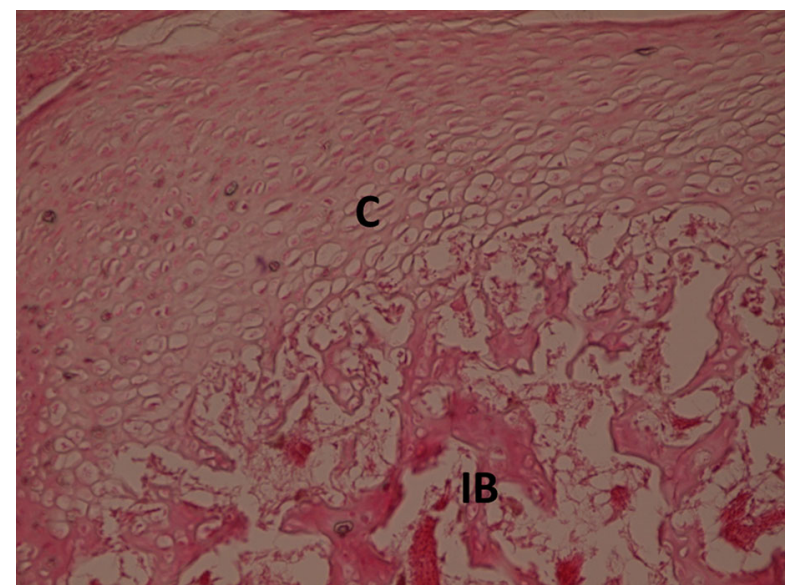

Fig. 9. Control group stage 8 recovery: Image shows immature bone (IB) and little cartilage (C) tissue (haemotoxylin and eosin staining $\times 200$ magnification).

investigated by forced movements to the fractured fibula in two planes, and radiology provided an additional evaluation. Dimar et al. (10) emphasised clinical examination in two planes for stability evaluation and the approach in the current study supports this.

Some histopathological evaluations related to fracture healing have given qualitative results rather than numerical values $(29,30)$. Allen et al. (31-33) reported a 5-stage histopathological evaluation. However, Huo et al. (12) recommended a more comprehensive method, which was used in the current study. By examination of 10 stages in this system, more detailed and accurate results are obtained $(28,34,35)$.

Physiological and pathological events in living organisms occur as a result of substances which may have harmful effects. The most important of these are free oxygen radicals which are balanced by the body's antioxidant system (36). The effects of antioxidant molecules on

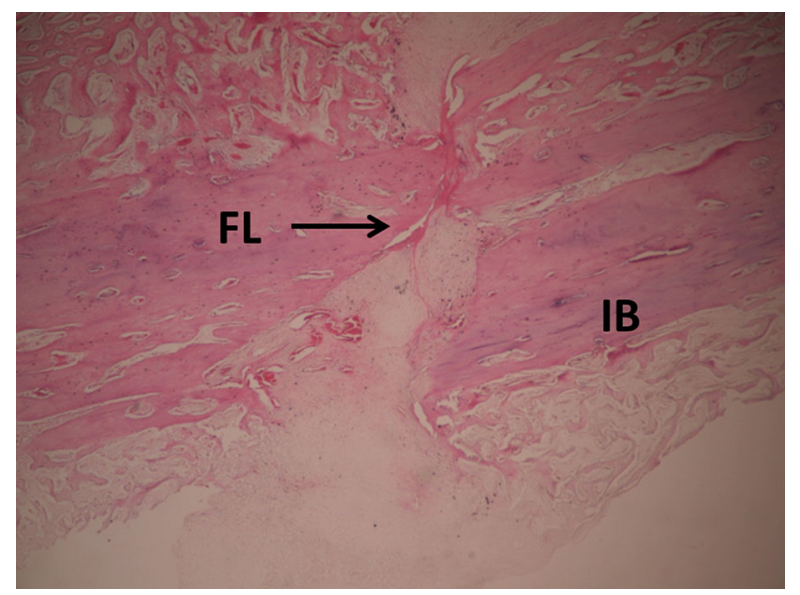

Fig. 10. Immunonutrition group stage 9 recovery: section from fracture line (FL) showing complete immature bone tissue (IB) (haemotoxylin and eosin staining $\times 40$ magnification).

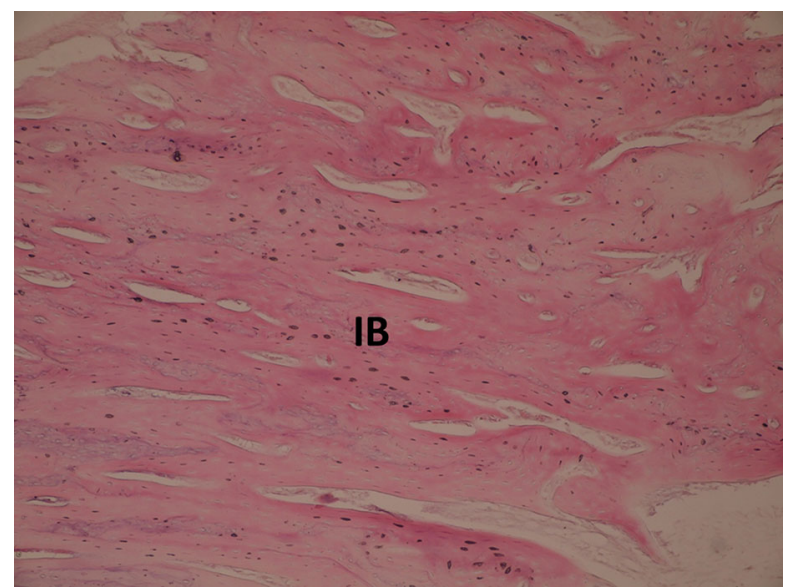

Fig. 11. Immunonutrition group stage 9 recovery: complete immature bone tissue (IB) (haemotoxylin and eosin staining $\times 100$ magnification).

fracture healing have been examined with particular focus on some vitamins and essential amino acids $(4,31,33,37-$ 39). As part of the antioxidant system, glutamine being a precursor of the glutathione-peroxidase enzyme, also serves as an antioxidant. Studies by Durak et al. (40) and Sarisözen et al. (31) emphasised that the effect of antioxidants in reducing free oxygen radicals found in fracture haematoma may have a positive effect on fracture healing. Therefore, in the current study it was thought that as well as other effects, glutamine as an antioxidant could positively influence fracture healing by reducing free oxygen radicals found in the fracture area, but indicators related to this were not examined.

In a study on rabbits by Sinha and Goal (41), where the amino acids lysine and arginine were administered orally, increased callus vascularisation and mineralisation was reported and the healing period was accelerated to 2 weeks. In an experimental study by Kdolsky et al. (42) a femoral diaphysis defect was created in guinea pigs and intramedullary fixation was applied to the femur with a $\mathrm{k}$-wire. The findings were evaluated histologically, mechanically, and radiologically and it was concluded that the animals which had received L-Arginine had better fracture healing and mechanical stability. Comparing the current study to that one, the amino acid used was glutamine, the fibula was used rather than the femur, and there was no mechanical evaluation. Therefore, although the idea of the effect of amino acids on fracture healing is similar, from a technical aspect there is no similarity to the current study.

In the histological evaluation of the current study, all the rabbits that had received glutamine were seen to be at stage 9 full recovery, whereas half of the control group were at stage 8 recovery with cartilage and immature bone together and the others were at stage 9 recovery. This finding justifies the view that glutamine has a positive effect on 
fracture healing. However, no statistically significant difference was determined between the two groups. Similarly, in the radiological evaluation, the immunonutrition group was determined as mean 3.42 points from a total of 5 by the orthopaedic and traumatology specialists and mean 3.35 points by the radiology specialists whereas the control group points were low at mean 2.5 and 2.65 respectively. Despite the difference between them, there was no statistically significant difference. This is thought to be because of the low number of animals used in this study. It is also thought that histological evaluation at an earlier stage of healing may yield significant results.

In conclusion, despite the beneficial effects of glutamine on the speed of wound healing and reducing morbidity and mortality rates in sepsis, and the positive effect observed on bone healing in the immunonutrition group clinically, radiologically, and histopathologically, no statistically significant difference was determined compared to the control group in this study. Additional light will be shed on this subject in literature by subsequent research considering different parameters.

\section{Conflict of interest and funding}

There is no conflict of interest of any author of this case report.

\section{References}

1. Giannoudis PV, Einhorn TA, Marsh D. Fracture healing: the diamond concept. Injury 2007; 38: 3-6.

2. Kılıçoğlu SS. Mikroskobi düzeyinde kırık iyileşmesi. Ank Üni Tip Fak Mecm 2002; 2: 143-50.

3. Coster J, McCauley R, Hall J. Glutamine: metabolism and application in nutrition support. Asia Pac J Clin Nutr 2004; 13: 25-31.

4. Keskin D, Karsan O, Ezirmik N, Çiftioğlu A. Tavşanlarda kırık iyileşmesine alfa-Tokoferol'ün etkisi. Exper Res 1999; 10: 207-10.

5. Göktürk E. Sıçanlarda serbest oksijen radikallerinin kırık iyileșmesi üzerine etkisi. Acta Orthop Traumatol Turc 1997; 31: 353-6.

6. Grimble RF. Immunonutrition. Curr Opin Gastroenterol 2005; 21: 216-22.

7. Collins N. Glutamine and wound healing. Adv Skin Wound Care 2002; 15: 233-4.

8. Kuhn SK, Muscaritoli M, Wischmeyer P, Stehle P. Glutamine as indispensable nutrient in oncology: experimental and clinical evidence. Eur J Nutr 2010; 49: 197-210.

9. Lane JM, Sandhu HS. Current approaches to experimental bone grafting. Orthop Clin North Am 1987; 18: 213-25.

10. Dimar JR, 2nd, Ante WA, Zhang YP, Glassman SD. The effects of nonsteroidal anti-inflammatory drugs on posterior spinal fusions in the rat. Spine 1996; 15: 1870-6.

11. Luna LG, editors. Manual of histologic staining methods of the Armed Forces Institute of Pathology. 3rd ed. New York: McGraw-Hill Book Company; 1960, p. 9.

12. Huo MH, Troiano NW, Pelker RR, Gundberg CM, Friedlaender GE. The influence of ibuprofen on fracture repair: biomechanical, biochemical, histologic, and histomorphometric parameters in rats. J Orthop Res 1991; 9: 383-90.
13. Reitzer LJ, Wice BM, Kennell D. Evidence that glutamine, not sugar, is the major energy source for cultured HeLa cells. J Biol Chem 1979; 254: 2669-76.

14. Deniel N, Letellier MR, Charlionet R, Tron F, Leprince J, Vaudry $\mathrm{H}$, et al. Glutamine regulates the human epithelial intestinal HCT-8 cell proteome under apoptotic conditions. Mol Cell Proteomics 2007; 6: 1671-9.

15. Noe JE. L-glutamine use in the treatment and prevention of mucositis and cachexia: a naturopathic perspective. Integr Cancer Ther 2009; 8: 409-15.

16. Öztürk ME. Preoperatif Alanin-Glutaminden zenginleştirilmiş Diyet'in Elektif Kolon Anastomozu Üzerine Etkileri (Deneysel Çalışma). Uzmanlık Tezi, Sağlık Bakanlığı Dr.Lütfi Kırdar Kartal Eğitim ve Araştırma Hastanesi, İstanbul, 2004.

17. Wilmore DW. The effect of glutamine supplementation in patients following elective surgery and accidental injury. J Nutr 2001; 131: 2543-9.

18. Boelens PG, Nijveldt RJ, Houdijk AP, Meijer S, van Leeuwen PA. Glutamine alimentation in catabolic state. J Nutr 2001; 131: 2569-77.

19. Mok E, Hankard R. Glutamine supplementation in sick children: is it beneficial? J Nutr Metab 2011; 2011: 617597.

20. Newsholme P. Why is L-glutamine metabolism important to cells of the immune system in health, postinjury, surgery or infection? J Nutr 2001; 131: 2515-22.

21. Roth E. Nonnutritive effects of glutamine. J Nutr 2008; 138: 2025-31.

22. Curi R, Newsholme P, Pithon-Curi TC, Pires-de-Melo M, Garcia C, Homem-de-Bittencourt PI, et al. Metabolic fate of glutamine in lymphocytes, macrophages and neutrophils. Braz $\mathrm{J}$ Med Biol Res 1999; 32: 15-21.

23. Fini M, Aldini NN, Canè V, Zaffe D, Giavaresi G, Rocca M, et al. Effects of essential amino acids and lactose on bony fractures and defects in rabbits: a preliminary histomorphometric study. Arch Orthop Trauma Surg 1999; 119: 39-45.

24. Schmidmaier G, Wildeman B, Ostapowicz D, Kandziora F. Long term effects of local growth factor (IGF-I and TGF- $\beta 1$ ) treatment on fracture healing: a safety study for using growth factors. J Orthop Res 2004; 22: 504-19.

25. Bulut O, Eroglu M, Ozturk H, Tezeren G, Bulut S, Koptagel E. Extracorporeal shock wave treatment for defective nonunion of the radius: a rabbit model. J Orthop Surg 2006; 14: 133-7.

26. Kaygusuz MA, Turan CC, Aydın NE, Temel İ, Firat S, Bulut T, et al. The effects of G-CSF and naproxen sodium on the serum TGF- $\beta 1$ level and fracture healing in rat tibias. Life Sci 2006; 80: $67-73$.

27. Korkmaz M, Oztürk H, Bulut O, Unsaldi T, Kaloğlu C. The effect of definitive continuous distraction employed with the Ilizarov type external fixation system on fracture healing: an experimental rabbit model. Acta Orthop Traumatol Turc 2005; 39: $247-57$.

28. Akman S, Gögüs A, Sener N, Bilgiç B, Aksoy B, Seckin F. Effect of diclofenac sodium on union of tibial fractures in rats. Adv Ther 2002; 19: 119-25.

29. Einhorn TA, Majeska RJ, Mohaideen A, Kagel EM. A single percutaneous injection of recombinant human bone morphogenetic protein-2 accelerates fracture repair. J Bone Joint Surg 2003; 85: 1425-35.

30. Kirker CA, Gerhart TN, Armstrong N, Schelling SH, Carmel LA. Healing bone using recombinant human bone morphogenetic protein 2 and copolymer. Clin Orthop Relat Res 1998; 349: 205-17.

31. Sarisözen B, Durak K, Dinçer G, Bilgen OF. The effects of vitamins $\mathrm{E}$ and $\mathrm{C}$ on fracture healing in rats. $\mathrm{J}$ Int Med Res 2002; 30: 309-13. 
32. Göktürk E, Turgut A, Bayçu C, Günal Ġ. Oxygen-free radicals impair fracture healing in rats. Acta Orthop Scand 1995; 66: $473-5$.

33. Durak K, Sonmez G, Sarisozen B, Ozkan S, Kaya M, Ozturk C. Histological assessment of the effect of alpha-tocopherol on fracture healing in rabbits. J Int Med Res 2003; 31: 26-30.

34. Huddleston PM, Steckelberg JM, Hanssen AD, Rouse MS Bolander ME, Patel R. Ciprofloxacin inhibition of experimental fracture healing. J Bone Joint Surg Am 2000; 82: 161-73.

35. Oetgen ME, Merrell GA, Troiano NW, Horowitz MC, Kacena MA. Development of a femoral non-union model in the mouse. Injury 2008; 39: 1119-26.

36. Özan F. Propolis'in Kırık İyileșmesi Üzerine Etkilerinin Deneysel Olarak İncelenmesi. Doktora Tezi, Sivas Cumhuriyet Üniversitesi, Sivas, 2006.

37. Yilmaz C, Erdemli E, Selek H, Kinik H, Arikan M, Erdemli B. The contribution of vitamin $\mathrm{C}$ to healing of experimental fractures. Arch Orthop Trauma Surg 2001; 121: 426-8.

38. Türk C, Halıcı M, Güney A, Akgün H, Șahin V, Muhtaroğlu S. Promotion of fracture healing by vitamin $\mathrm{E}$ in rats. J Int Med Res 2004; 32: 507-12.
39. Guney A, Karaman I, Oner M, Yerer MB. Effects of propolis on fracture healing: an experimental study. Phytother Res 2011; 25: $1648-52$.

40. Durak K, Bilgen OF, Kaleli T, Tuncel P, Ozbek R, Turan K. Antioxidant effect of alpha-tocopherol on fracture haematoma in rabbits. J Int Med Res 1996; 5: 419-24.

41. Sinha S, Goel SC. Effect of amino acids lysine and arginine on fracture healing in rabbits: a radiological and histomorphological analysis. Indian J Orthop 2009; 43: 328-34.

42. Kdolsky RK, Mohr W, Savidis HD, Beer R, Puig S, Reihsner R, et al. The influence of oral L-arginine on fracture healing: an animal study. Wien Klin Wochenschr 2005; 117: 693-701.

\section{*Abdullah Küçükalp}

Yesilyayla District 4.Yoruk Street Number: 4/4

Yildirim/Bursa Turkey PC: 16330

Email: karalama@mynet.com 